\title{
Diagnosis of the floristic diversity in south of Saida (steppe west Algerian)
}

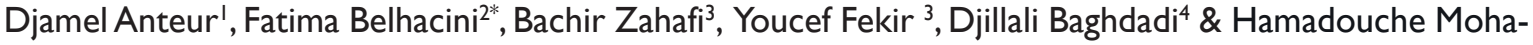 \\ med Amine ${ }^{3}$
}

${ }^{1}$ Research Laboratory "Water and Environment” University Molay Thar of Saïda Algeria

${ }^{2}$ Research Laboratory Ecology and Management of Natural Ecosystems, Tlemcen Algeria, University Hassiba Benbouali of Chlef Algeria

${ }^{3}$ Recherch Laboratory Biological Systems and Geomatics, University Mustapha Stambouli of Mascara, Algeria

${ }^{4}$ Ahmed Zabana University Center, 48000 Relizane, Algeria

"Corresponding author, email: eco_vert7@yahoo.fr

\begin{abstract}
This work allowed to make an assessment of the floristic diversity in south of Saida, in western Algeria, based on the phytoecological aspect, biological, morphological and biogeogaphical of this heritage. Given the nature of the problem to be addressed, we used the Zuricho Montpelieraine according to the Braun-Blanquet method: we harvested all plant species encountered, listed the species on a surface plot (area minimum), and registered the floristic surveys. The floristic diversity is relatively low compared to other oranaises areas in Algeria, it is closely linked to the severe climatic conditions coupled with a strong anthropozoic action which translates by the preponderance of species such as: Artemisia herba-alba Asso, Atriplex halimus L., Peganum harmala L., Salsola vermiculata L. Currently the conservation of different taxa are scientific priorities for assessment and management of this biological heritage.
\end{abstract}

KEY WORDS Systematics; Biology; Biogeography; South of Saida; western Algeria.

Received 04.02.2020; accepted 08.04.2021; published online 28.04.2021

\section{INTRODUCTION}

According to Barry (1988), the term "steppe" evokes huge arid areas covered with low, sparse vegetation. These arid and semi-arid regions predominantly located by and on the other of the tropics are buffers between the relatively well-watered lands and deserts. The steppe areas are characterized by a climate of Mediterranean type, contrasted with a hot and dry summer, alternating with a rainy, cool or cold winter (Braun-Blanquet et al., 1951).

The North African steppes in general, and Algerian in particular, are the Mauritanian-steppe flora domain defined by Dahmani (1997).
Generally, dryland benefited to date attention in relation to their contribution to national and international strategies of preservation, conservation and valorisation of their biodiversity. This is especially the case in circum-Saharan Africa.

Biological diversity in the circum-Saharan zone should be inventoried and monitored.

To ensure the maximum quantities and the quality of renewable resources, it is necessary to learn to use them sustainably in particular taking into account speed healing of ecosystems and maintaining the capacity of resilience.

As noted by Cornet $(2000,2002)$, plant diversity in circum-Saharan zone presents original flora. The 
peculiarities of such floras reside in the existence of original genetic resources and specific habitats, resulting from process of adaptation and evolution in response to the increasing aridity and a former anthropogenic pressure.

People must consider the plants, not only as a global humanity's heritage, but also as one of the potential bases of local development in relation to the biological diversity; its utilization and conservation should therefore not be restricted to areas of high wealth ("hot spots") but extended to all the regions of the world.

Generally, dry areas have not benefited from attention given their contribution to national and international strategies on the conservation and recovery of biological diversity. However, since the Rio conference in 1992, the fight against desertification and the conservation of biological diversity in dry areas were highlighted, particularly in circum-Saharan Africa.

One of the main objectives of this study is to identify the floristic, biological, morphological and biogeographical distribution of species characterizing the studied area, which will allow to better taking into account the value of the phytodiversity in order to better preserve it and keep it.

\section{MATERIAL AND METHODS}

The study area is located on the high plains oranaises (Fig. 1). It is located $90 \mathrm{Km}$ South-East of the wilaya of Saïda and $530 \mathrm{Km}$ to the southWest of Algiers. Administratively, it is located in

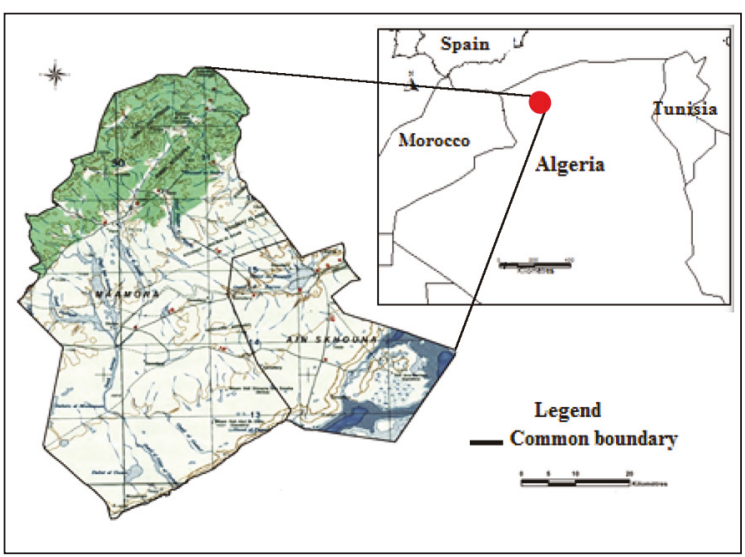

Figure 1. Location of the study area. the wilaya of Saïda, limited to the east and to the north by the wilaya of Tiaret, and on the south by the wilaya of El Bayadh. Following the recognition of the land, a sampling plan is essential to establish in order to allow the realization of floristic inventory in the area study.

We thought that the method of Braun-Blanquet et al. (1951) is the most appropriate to better control the floristic cortege and the objectives of the study. It allows a comprehensive study of the vegetation and its biogeographical distribution.

An area with a predominance of sheep farming which receives an average rainfall not exceeding $250 \mathrm{~mm}$ per year is largely marked by the irreversible degradation of the steppe and risks the desertification.

To give a more accurate picture of the actual vegetation and to better quantify vegetation, Godron (1971) adds that the most common procedure is the curve "area-species".

Lemee (1967) defines as "area minimum" the smallest area needed in which most species are represented.

\section{RESULT AND DISCUSSION}

The family and the kind of all species are determined by Quézel \& Santa (1962-1963).

At the level of the study area, the genera represented are variable; the distribution of families is heterogeneous (Fig. 2).

The Asteraceae family, the Poaceae the Amarantaceae, the Lamiaceae, the Cistaceae and Boraginaceae dominate the study area, these families represent more than $62 \%$ of the studied flora.

Other families have very low percentages and sometimes are typically mono-generics and monospecific. In arid zones and in the Sahara, most of the families are represented by one or two genera, and most genera by only one or two species. This richness may be explained by drastic climatic conditions and practice of agriculture and livestock.

Forms and life of plants represent a tool for description of physiognomy and structure of the vegetation. They are considered as an expression of the coping strategy of flora and vegetation to environmental conditions.

The biological types of the species express the existence of the plants in an environment without 
taking account of their systematic level. They translate biology and an adaptation to the environment according to Barry (1988).

Biological types by their distribution faithfully reflect the ecological conditions of a region (Fig. 3 ). The study area is marked by a high percentage of therophytes (Th), $51 \%$ then come the chamaephytes (Ch) with $24 \%$. Geophytes (Ge) and the Hemicryptophytes $(\mathrm{He})$ are poorly represented with only $6 \%$ and $16 \%$. Finally, the Phanerophytes $(\mathrm{Ph})$ are the least represented, overall 3\%, reflecting the state of the environment under the action of ecological and, especially, human phenomena Gadrat (1999) and Romane (1987) highlight the existence good correlation between biological types and many morphological characters: annual herbs, perennial herbs, perennial woody (Fig. 4).

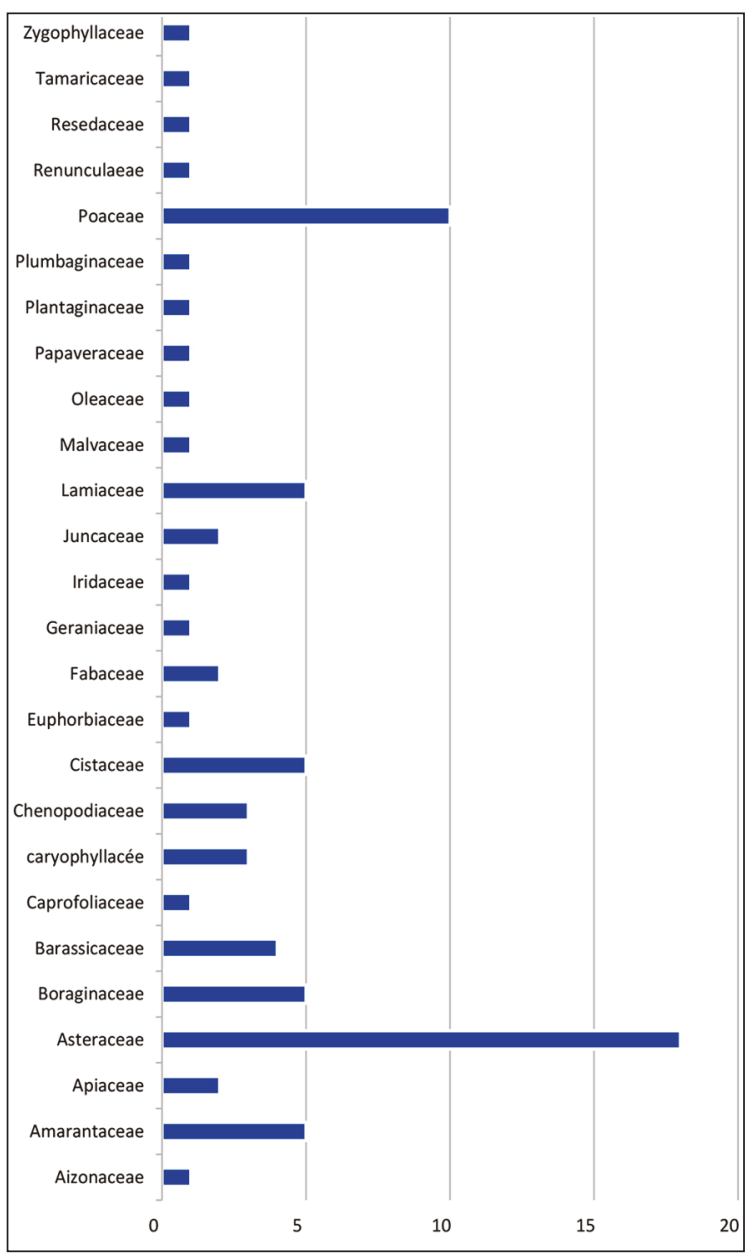

Figure 2. Families, genera and species composition.
The form of the plant is one of the basic criteria for the classification of biological species. Biomass is composed of woody, perennial, annual and herbaceous species.

Our research has revealed the dominance of perennial herbs and perennial woody ( $88 \%)$. This is justified by the fact that this vegetation is very much subjected to human pressure.

On the other hand, perennial grasses dominate the annual weeds.

Biogeographical spectrum (Fig. 5), based on the overall floristic list of the territory, highlights the various elements; the study the distribution of these species was based on the information provided by Quézel \& Santa (1962-1963).

Chorology perspective, the percentage of taxa in mediterranean distribution is quite high, $20.28 \%$ of the total.

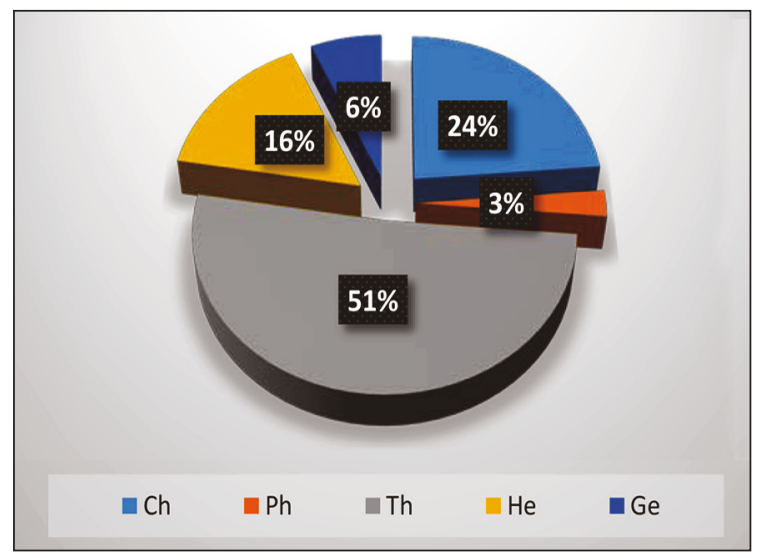

Figure 3. Percentage of biological types.

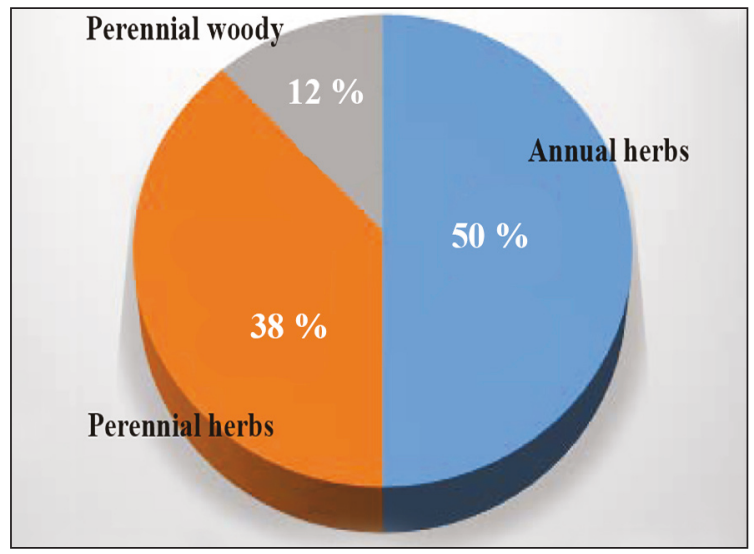

Figure 4. Percentage of morphological types. 


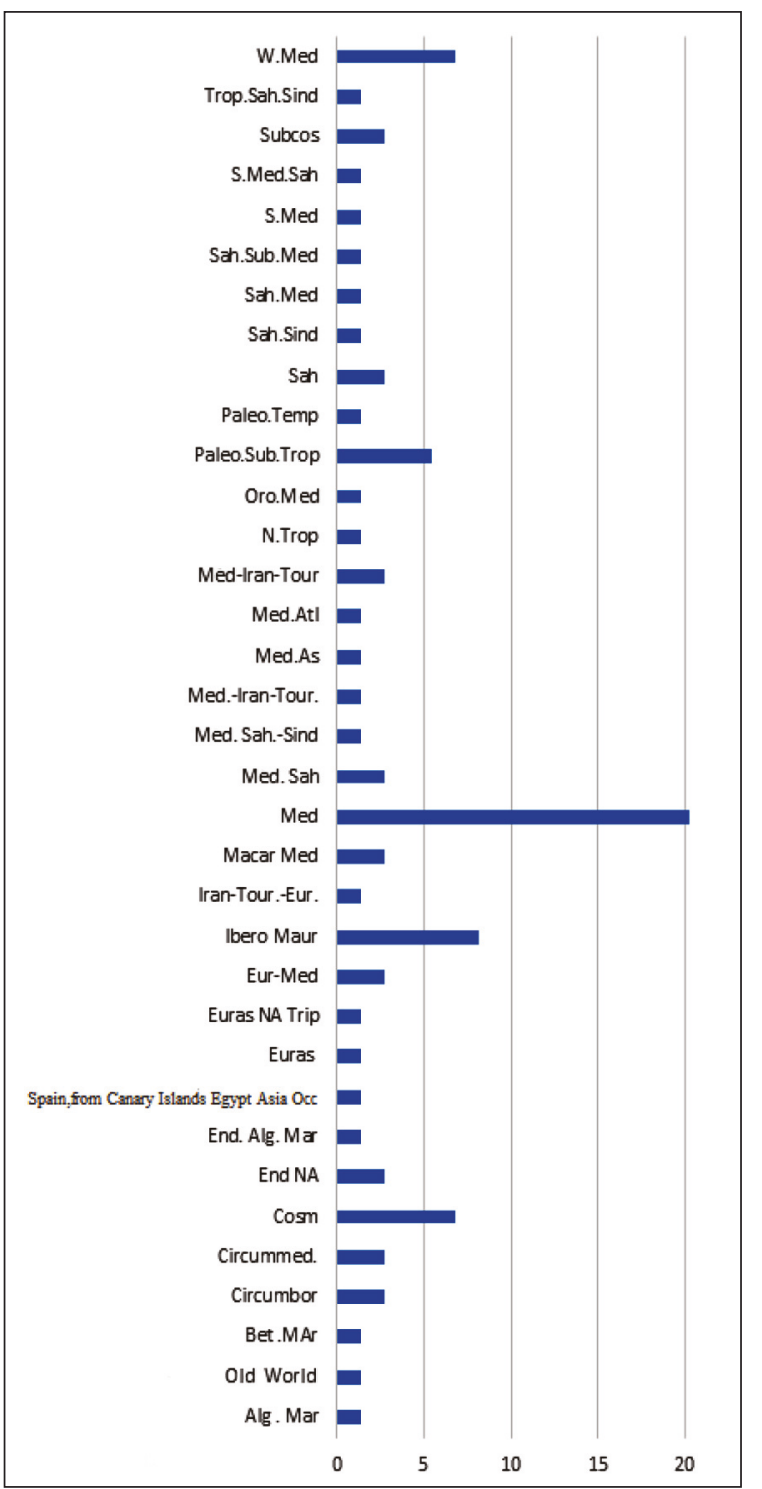

Figure 5. Distribution of biogeographic types.

Taxa of Mauritanian-Ibero and Cosmopolitan origin occupy a significant place in the study area, respectively, $8.12 \%$ and $6.77 \%$ of the total work force.

\section{CONCLUSIONS}

Land degradation causes an overall amendment of the biogenesis with its biotope, these changes thus impact on biodiversity and the functional processes of the plant and thus on the resilience of ecological systems.
The floristic richness in the south of the Saida steppe to the west of Algeria is mainly represented by the Asteraceae, Amarantaceae, Lamiaceae and Poaceae families capable of withstanding the extreme ecological conditions of these territories.

Biogeographical distribution shows the dominance of the Mediterranean element (20.28\%), then those of Mauritanian-Ibero with $8.12 \%$.

The chamaephytiques and the therophytes are the most represented species, reflecting a strong anthropic action that creates drying out phenomena (Orshan et al., 1984; Floret et al., 1990). They are better adapted to summer drought and strong lighting according to Danin \& Orshan (1990). Therefore the adaptations of these species in unfavorable conditions also represent a form of resistance to climatic rigors according to Negro (1966) and Daget (1980).

\section{REFERENCES}

Braun-Blanquet J., Roussine Mme. N. \& Négre R., 1951. Les groupements végétaux de la France méditerranéenne. Centre national de la recherche scientifique, $298 \mathrm{pp}$.

Barry J.-P., 1988. Approche Ecologique des Régions Arides de l'Afrique. Université de Nice. ISS de Nouakchott, $107 \mathrm{pp}$.

Cornet A., 2000. Désertification: un problème environnemental, un problème de développement. Conférence invitée, La Londe les Maures, 2000, France.

Cornet A., 2002. La désertification à la croisée de l'environnement et du développement : un problème qui nous concerne, Sommet du Développement Durable, Johannesburg: pp. 93-130.

Dahmani-Megrerouche M., 1997. Le chêne vert en Algérie. Syntaxonomie, phytosociologie et dynamique des peuplements. Thèse doct. ès-sciences. Université Houari Boumediene, Alger, 329 pp. + annexes.

Daget P.H., 1980. Sur les types biologiques botaniques en tant que stratégie adaptative, cas des thérophytes. In "Recherches d'écologie théorique". Les stratégies adaptatives, pp. 89-114.

Danin A. \& Orshan G., 1990. The distribution of Raunkiaer life forms in Israel in relation to the environment. Journal of Vegetation Science, 1: 41-48.

Floret C.H., Galan M.J., Le Floc H., Orshan G. \& Romane F., 1990. Growth forms and phenomorphology traits along an environmental gradient: tools for studing vegetation. Journal of Vegetation Science, 1: 71-80.

Gadrat B., 1999. Shape of plants. Site web: www.designvegetal.com 
Godron M., 1971. Essai sur une approche probabiliste de l'écologie des végétaux. Thèse, Montpellier, $247 \mathrm{pp}$. Lemee G., 1953. Contribution à la connaissance phytosociologique des confins saharo-marocains. Les associations a thérophytes des dépressions sableuses et limoneuses non salées et des rocailles aux environs de Beni Ounif. Vegetatio, 4: 137-154.

Négre R., 1966. Les thérophytes. Mémoire Societè Botanique France, 92-108.

Orshan G., Montenegro G., Avila G., Aljaro M.E., Walckowiaak A. \& Mujica A.M., 1984. Plant growth forms of Chilean matoral. A monocharacter growth form analysis along an altitudinal transect from sea level to $2000 \mathrm{~m}$ a.s.l. Bulletin de la Société Botanique de France, 131: 411-425.

Quézel P. \& Santa S., 1962-1963. Nouvelle Flore d'Algérie et des Régions Désertiques Méridionales. 2 Tomes, Editions CNRS, Paris, 1170 pp.

Romane F., 1987. Efficacité de la distribution des formes de croissance pour l'analyse de la végétation à l'échelle régionale. Thèse Doct. Université Marseille. 
